\title{
Thalidomide's effectiveness in erythema nodosum leprosum is associated with a decrease in CD4 + cells in the peripheral blood
}

\author{
E J SHANNON, $*$ MESTAWAT EJIGU, $\dagger$ \\ H S HAILE-MARIAM, $\dagger$ TEBEBE YEMANE BERHAN $\dagger$ \\ \& GENET TASESSE $\ddagger$ \\ *Pharmacology Research Department, G.W. Long Hansen's Dis- \\ ease Center, Carville, La, 70721, USA; †All Africa Leprosy \\ Rehabilitation and Training Centre, Addis Ababa, Ethiopia; \\ $\ddagger$ Armauer Hansen Research Institute, Addis Ababa, Ethiopia
}

Accepted for publication 18 September 1991

\begin{abstract}
Summary Thalidomide is well documented as being an effective drug in the treatment of erythema nodosum leprosum (ENL). The mechanism of action of thalidomide in ENL as well as the pathogenesis of ENL are yet to be fully determined.

Lepromatous leprosy patients experiencing ENL have been reported to have an increase in the ratio of CD4 + to CD8 + cells in their blood and ENL skin lesions. Thalidomide has been shown to cause a decrease in the ratio of CD4+ to CD8 + lymphocytes in the blood of healthy males. This decrease was due to a significant reduction in the numbers of CD4+ lymphocytes and an apparent increase in the numbers of CD8 + lymphocytes.

In this study, thalidomide's effectiveness in halting chronic ENL and arresting a relapse into ENL was consistently associated with a decrease in the numbers of CD4 + lymphocytes in the blood of 2 male lepromatous leprosy patients.
\end{abstract}

\section{Introduction}

Thalidomide, $\alpha$-phthalimido-glutarimide, dramatically relieves the signs and symptoms of erythema nodosum leprosum (ENL), an acute inflammatory complication of lepromatous leprosy. How thalidomide acts on ENL, and what the pathogenesis of ENL is, has not yet been fully determined.

It has been suggested that ENL is caused by an imbalance in immunoregulatory Tlymphocyte subsets. ${ }^{1,2}$ In association with the acute phase of ENL is an increase in the ratio of helper/inducer T cells $(\mathrm{CD} 4+)$ to suppressor/cytotoxic $\mathrm{T}$ cells $(\mathrm{CD} 8+)$ in peripheral blood. ${ }^{1,3,4}$ This imbalance in blood lymphocyte subpopulations seems to be 
unique to the ENL reactional patient and does not occur during quiescent lepromatous disease.

In a previous study, ingestion of $200 \mathrm{mg}$ of thalidomide daily for 4 days caused a decrease in the ratio of Leu-3a monoclonal antibody positive $(\mathrm{CD} 4+)$ to Leu-2a monoclonal antibody positive $(\mathrm{CD} 8+)$ lymphocytes in the blood of healthy males. ${ }^{5}$ This decrease was due to a significant reduction in the percentage and absolute numbers of CD4 + cells and an apparent increase in the percentage and absolute numbers of CD8 + cells.

This observation in healthy males and the reported alterations in the proportions of CD4 + and CD8 + cells in patients with acute ENL prompted us to speculate that thalidomide's effectiveness in ENL may be associated with a change in the population of CD4 + or CD8 + cells in blood. ${ }^{5}$ After receiving informed consent from two male Ethiopian patients with chronic ENL, we tested this hypothesis.

\section{Materials and methods}

PATIENTS

Patient No. 943 is a 33-year-old male Ethiopian. He is classified as lepromatous with chronic ENL (LL/ENL) and had been under DDS monotherapy for 14 years before being referred to ALERT for recurring ENL. He was placed on high doses of clofazimine without improvement and was then started on steroids. He responded to high doses of steroids, but ENL reoccurred when the steroids were reduced to below $20 \mathrm{mg}$ daily. $\mathrm{He}$ was then started on thalidomide. Upon completion of a four-day course of $400 \mathrm{mg}$ of thalidomide daily, his condition improved. However, the ENL lesions reoccurred upon discontinuation of thalidomide and a similar course of treatment with thalidomide was reinitiated. His condition improved. Thalidomide became unavailable and he was returned to maintenance doses of steroids and $100 \mathrm{mg}$ daily of clofazimine. This regimen continued for approximately 3 months. Then, af ter giving informed consent, on 21 July 1989 therapy with steroids was discontinued. He progressively lapsed into ENL and on 24 July 1989 treatment with thalidomide was once again initiated. Thalidomide (Grunenthal GMBH, 5190 Stolberg/Rhld, Germany) was taken orally in doses of $100 \mathrm{mg}$ every $12 \mathrm{hr}$ for 3 days. A the end of 3 days' treatment the thalidomide was stopped, and the patient progressively relapsed into ENL -7 days after the thalidomide was stopped thalidomide therapy was re-initiated with oral doses of $100 \mathrm{mg}$ every $12 \mathrm{hr}$ for 3 days.

Patient No. 944 is a 31 -year-old male Ethiopian. He is a known LL patient since 1987 and is currently under multidrug therapy. He was referred to ALERT because of recurring ENL. He was placed on high doses of clofazimine, but in vain. He responded to high doses of steroids (up to $60 \mathrm{mg} /$ day) but ENL reoccurred on lowering the dose of steroids. He was on maintenance doses of steroids and doses of $100 \mathrm{mg}$ daily of clofazimine. After giving informed consent, on 21 July 1989 therapy with steroids was discontinued. He lapsed into ENL and on 24 July 1989 treatment with thalidomide was initiated. His course of treatment with thalidomide was similar to that described for patient No. 943.

\section{CELL SEPARATION}

On four separate occasions $30 \mathrm{ml}$ blood was drawn in the morning from each patient. 
Approximately $10 \mathrm{ml}$ blood was given to the clinical laboratory for a complete blood count, assessment of the erythrocyte sedimentation rate, and the content of haemoglobin. The remaining blood was defibrinated by shaking with glass beads for $10-15 \mathrm{~min}$. The defibrinated blood was centrifuged for $20 \mathrm{~min}$ at $450 \times G$. The serum was removed and the pellet was diluted in 3 volumes of saline and layered on Ficoll-Hypaque. After centrifugation at $400 \times G$ for $35 \mathrm{~min}$ at $20^{\circ} \mathrm{C}$ the mononuclear cells were collected and washed using RPMI-1640.

\section{DETERMINATION OF T-CELL PHENOTYPES}

T-lymphocyte phenotypes were determined using fluorescein-conjugated monoclonal antibodies, Leu-1 (T-cells, CD5+), Leu-2a (cytotoxic/suppressor, CD8+), Leu-3a (helper/inducer, CD4+) (Becton Dickinson, Sunnyvale, CA, USA). The fluorescence was amplified by using fluorescein-conjugated rabbit antimouse Ig (DAKOPATTS, a/s, Denmark). Absolute numbers of lymphocytes bearing a given cluster differentiation antigen (CD) were calculated from a product of (a) leukocyte counts, (b) percentage of lymphocytes from differential counts, and (c) percentage of mononuclear cells that fluoresced with a particular fluorescein-conjugated antibody.

\section{Results}

A consistent reduction in the numbers of CD5 + and CD4 + lymphocytes was noted in both patients after effective treatment of their ENL with thalidomide whereas minimal changes in the numbers of CD8 + lymphocytes were observed (Figure 1).

After the second 3-day regimen with thalidomide, both patient 943 and patient 944 remained free of ENL. After 1 month, they were discharged from the hospital. During the past year, the patients have been seen occasionally at ALERT. Neither of the two patients has relapsed with ENL.

\section{Discussion}

Clinically, ENL is characterized by fever and a sudden eruption of acute inflammatory lesions in areas harbouring large numbers of Mycohacterium leprae. Histologically, the hallmarks of ENL skin lesions are vascular necrosis, oedema, and inflammation with infiltrates of neutrophils affecting the entire dermis and subcutaneous fat. ${ }^{6}$ The factor(s) which cause the influx of neutrophils into lesions is unknown. Immune complexes and cell-mediated mechanisms have been implicated in ENL. ${ }^{2}$

A disturbance in immunoregulation by $\mathrm{T}$-cells is thought to be a fundamental occurrence during ENL. Patients experiencing ENL have an augmented in vivo responsiveness to sensitizers like dinitrochlorobenzene ${ }^{7}$ and their lymphocytes in culture with mitogens increase in responsiveness. ${ }^{1,3,8}$ Lymphocytes from ENL reactional patients have also been shown to respond to $M$. leprae antigens in culture. ${ }^{8}$ Evidence for alterations in the numbers of lymphocytes expressing immunoregulatory molecules like CD4 and CD8 has accumulated from studies conducted on lymphocytes in the blood $1,3,4$ and in the skin lesions ${ }^{9-1.3}$ of lepromatous patients experiencing ENL. 


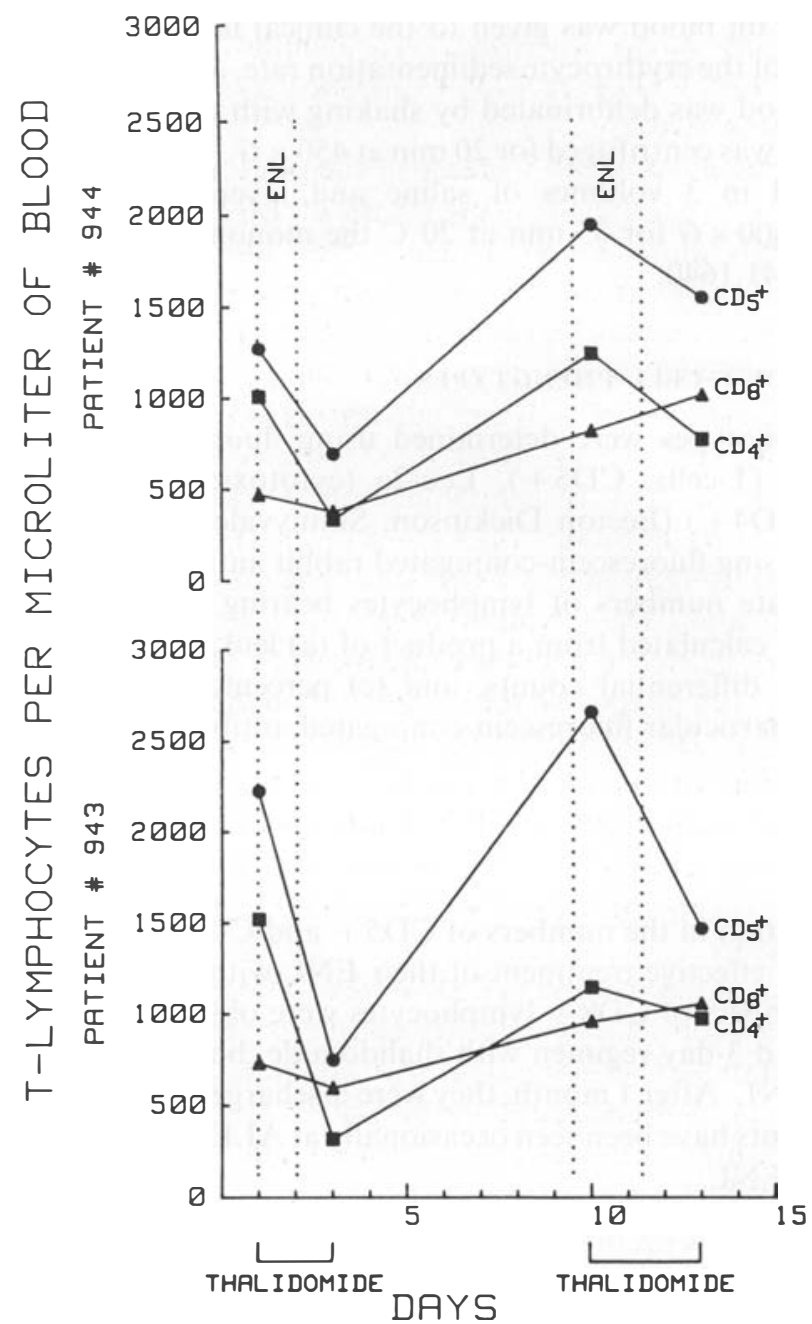

Figure 1. The effect of thalidomide on the number of peripheral blood T-cells (CD $5+$ ), T-helper/inducer cells $(\mathrm{CD} 4+)$ and $\mathrm{T}$-suppressor/cytotoxic cells $(\mathrm{CD} 8+)$.

In studies conducted on blood lymphocytes, lepromatous patients during ENL showed an increase in the per cent of helper cells, a decrease in the per cent of suppressor cells and a significant increase in the helper: suppressor ratio. ${ }^{1.4}$ In a study conducted in Ethiopia, Mshana et al. ${ }^{3}$ found ENL patients to have an increase in helper cells, a decrease in suppressor cells resulting in a high helper:suppressor ratio. Laal et al. ${ }^{8}$ showed a relative increase in the per cent of CD8 + cells in the blood of ENL patients in comparison with patients with stable lepromatous disease. Interestingly, these investigators also reported an in vitro lymphoproliferation to M. leprae antigens in lepromatous patients undergoing ENL reactions. Contrary to the above reports Modlin et al. ${ }^{12}$ showed that the percentage or numbers of T-helper or T-suppressor cells in ENL patients did not differ significantly from controls or lepromatous patients without ENL. 
The skin lesions of lepromatous patients without ENL have been shown to have an excess of CD8 + lymphocytes whereas CD4 + lymphocytes are prevalent in ENL skin lesions. ${ }^{9-11}$ A shift from CD8 + to CD4 + prevalence is also observed in patients from nonreactional LL to active ENL. ${ }^{13}$

The transient emergence of an increase in the per cent of T-helper cells in both the blood and skin lesions during the acute phase of ENL suggest that a target site for thalidomide in ENL may be the T-helper cell. Modulation of T-helper cells by thalidomide as a means to arrest ENL has been proposed. ${ }^{14,15}$ This speculation is also supported by the effectiveness of cyclosporin-A (CsA) in the treatment of ENL. ${ }^{14}$ While CsA affects several different cell types with immune potential, it consistently inhibits $\mathrm{T}$ helper cell function and a CD4 + lymphocytopenia is observed during treatment with high doses of the drug. ${ }^{16}$ Studies by Aszalos et al. ${ }^{17}$ showed that the membrane potential of CD4+ lymphocytes was selectively affected in patients immunosuppressed with CsA. Vogelsang et al., ${ }^{18}$ using fluorescent-activated cell sorting, reported that a fluorescent bioactive derivative of $\mathrm{CsA}$ and a fluorescent hydroxylated product of thalidomide reacted with $\mathrm{CD} 4+$ and $\mathrm{CD} 8+$ lymphocytes.

Thalidomide may be able to alter the expression of CD4 molecules by binding directly to them or reducing their density on the surface of lymphocytes or macrophages. Neither thalidomide nor its $\mathrm{pH}$ dependent hydrolysis products were able to bind directly to CD4 molecules and inhibit or reduce the intensity of fluorescence of mononuclear cells incubated with fluorescent-conjugated antibodies with specificity to CD5, CD4, and CD8. ${ }^{19}$ The influence of thalidomide on de novo synthesis of CD4 molecules or internalization of CD4 molecules on lymphocytes and macrophages are being investigated in our laboratory.

Interference with the expression of CD4 molecules by thalidomide could help explain many of the immunosuppressive properties ascribed to thalidomide. Thalidomide could also have additional sites of action as an immunosuppressive and anti-inflammatory drug in ENL. As examples, thalidomide has been shown to inhibit the production of TNFalpha by stimulated human monocytes. ${ }^{20}$ Thalidomide has been shown to inhibit IgM antibody synthesis. ${ }^{21}$ It has also been shown to stabilize lysosomal membranes from rat and human liver, has anti-inflammatory properties in carageenan rat paw oedema, antagonizes certain of the chemical mediators of inflammation (histamine, serotonin, prostaglandin $E_{2}$ and $F_{2}$ alpha) and inhibits the chemotaxis of neutrophils. ${ }^{22}$

\section{Acknowledgments}

We would like to thank the American Leprosy Missions for funding; the hospitality and laboratory facilities at AHRI are supported by the Norwegian and Swedish agencies for International Development (NORAD and SIDA); the members of the AHRI/ALERT Research Committee for their approval to conduct the study; and Dr D. Frommel for his administrative and scientific support.

\section{References}

1 Bach MA, Chatenoud L, Wallach D, Phan Din Tuy, Cottenot F. Studies on T cell subsets and functions in leprosy. Clin exp Imm, 1981; 44: 491-500. 
2 Mshana RN. Hypothesis: Erythema nodosum leprosum is precipitated by an imblance in T lymphocytes. Lepr Rev, 1982; 53: 1-7.

3 Mshana RN, Haregewoin A, Harboe M, Belehu A. Thymus dependent lymphocytes in leprosy. 1. T lymphocyte subpopulations defined by monoclonal antibodies. Int J Lepr, 1982; 50: 291-296.

4 Wallach D, Cottenot F, Bach MA. Imbalances in T cell subpopulations in lepromatous leprosy. Int J Lepr, 1982; 50: 282-290

5 Gad SM, Shannon EJ, Krotoski WA, Hastings RC. Thalidomide induces imbalances in T-lymphocyte subpopulations in the circulating blood of healthy males. Lepr Rev, 1985; 56: 35-39.

6 Job CK, Gude S, Macaden VP. Erythema nodosum leprosum. A clinicopathologic study. Int J Lepr, 1964; 32: $177-183$.

7 Rae TH, Levan NE. Variations in dinitrochlorobenzene responsivity in untreated leprosy: Evidence of a beneficial role for anergy. Int $J$ Lepr, 1980; 48: 120-125.

8 Laal S, Bhutani LK, Nath I. Natural emergence of antigen-reactive T cells in lepromatous leprosy patients during erythema nodosum leprosum. Infect Immun, 1985; 50: 887-892.

9 Modlin RL, Gebhard JF, Taylor CR, Rea TH. In situ characterization of T lymphocyte subsets in the reactional state of leprosy. Clin exp Imm, 1983; 53: 17-24.

10 Narayanan RB, Laal S, Sharma AK, Bhutrani KL, Natha I. Differences in predominant T cell phenotypes and distribution pattern in reactional lesions of tuberculoid and lepromatous leprosy. Clin exp Imm, 1984; 55: 623-628.

11 Wallach D, Flageul B, Bach MA, Cottenot F. The cellular content of dermal leprous granulomas and immuno-histological approach. Int J Lepr, 1984; 52: 318-326.

12 Modlin RL, Bakke AC, Vaccaro SA, Horwitz DA, Taylor CR, Rea TH. Tissue and blood T-lymphocyte subpopulations in erythema nodosum leprosum. Arch Dermatol, 1985; 121: 216-219.

13 Modlin RL, Mehra V, Jordan R, Bloom B, Rea T. In situ and In vitro characterization of the cellular immune response in erythema nodosum leprosum. J Immunol, 1986; 136: 883-886.

14 Miller RA, Jen-Yee Shen, Rea TH, Harnish JP. Treatment of chronic erythema nodosum leprosum with cyclosporin A produced clinical and immunological remission. Int J Lepr, 1987; 55: 441-449.

15 Moncada B, Baranda ML, Gonzalez-Amaro R, Urbian R, Loredo CE. Thalidomide-Effect on T cell subsets as a possible mechanism of action. Int J Lepr, 1985; 53: 201-205.

16 Dupont E. Immunological actions of corticosteroids and cyclosporine A. Current Opinion in Immunol, 1988; 1: $253-256$.

17 Aszalos A, Tron L, Paxton H, Shen S. Lymphocyte subpopulations with low membrane potential in the blood of cyclosporin- and prednisone-treatment patients: In vivo selectivity for T4 subset. Biochemical Med Metabol Biol, 1989; 41: 25-29.

18 Vogelsang GB, Hess AD, Gordon G, Brundrette R, Santos GW. Thalidomide induction of bone marrow transplantation tolerance. Transplant Proc, 1987; XIX: 2658-2661.

19 Shannon EJ, Hastings RC. In vitro effect of thalidomide on T-cells, T-suppressor and T-helper cells. Abstracted in 13th International Leprosy Congress, 11-17 September 1988, The Hague, The Netherlands.

20 Sampaio EP, Sarno EN, Galilly R, Cohn ZA, Kaplan G. Thalidomide selectively inhibits tumor necrosis factor alpha production by stimulated human monocytes. $J$ exp Med, 1991; 173: 699-703.

${ }^{21}$ Shannon EJ, Miranda RO, Morales MJ, Hastings RC. Inhibition of de novo IgM antibody synthesis by thalidomide as a relevant mechanism of action in leprosy. Scand J Immunol, 1981; 13: 553-562.

22 Hastings RC, Morales MJ, Shannon EJ. Studies on the mechanism of action of thalidomide in leprosy. Pharmacologist, 1976; 18:218-220. 


\title{
L'efficacité de la thalidomide contre l'erythema nodosum leprosum est associée à une diminution des cellules $\mathrm{CD} 4+$ du sang périphérique
}

\author{
E J Shannon, Mestawat Ejigu, H S Haile-Miriam, \\ Tebebe Yemane Berhan y Genet Tasesse
}

Résumé Bon nombre de documents ont prouvé l'efficacité de la thalidomide dans le traitement de l'erythema nodosum leprosum (ENL). Le mécanisme de l'action de la thalidomide contre l'ENL ainsi que la pathogénèse de l'ENL sont encore à démontrer.

On a décelé chez les patients atteints de lèpre lépromateuse sous la forme erythema nodosum leprosum un rapport plus élevé entre les cellules CD4 + et CD8 + dans le sang, ainsi que des lésions cutanées d'erythema nodosum leprosum. On a démontré que la thalidomide provoque une diminution du rapport entre les lymphocytes CD4 + et CD8 + dans le sang chez des subjets mâles sains. Cette diminution est due à une importante réduction du nombre des lymphocytes CD4 + et une augmentation apparente du nombre des lymphocytes CD $8+$.

Dans cette étude, conduite chez deux patients mâles atteints de lèpre lépromateuse, on constate une corrélation entre l'efficacité de la thalidomide prescrite pour stopper l'erythema nodosum leprosum chronique et empêcher une recidive de l'ENL et la diminution du nombre de lymphocytes CD4 + dans le sang.

\section{Se asocia la efectividad de la Talidomida en el eritema nodosum leprosum con una reducción de células $\mathrm{CD4}+$ en la sangre periférica}

\author{
E J Shannon, Mestawat Ejigu, H S Haile-Miriam, \\ Tebebe Yemane Berhan y Genet Tasesse
}

Resumen Se ha documentado bien la Talidomida como una droga ef ectiva en el tratamiento de eritema nodosum leprosum (ENL). Falta todaviva determinar completamente el mecanismo de actuación de la Talidomida en el ENL, como también la patogénesis del ENL.

Se ha informado que les pacientes con lepra lepromatosa que padecen de ENL presentan un aumento de la relación de células CD4 + a CD8 + en la sangre y las lesiones cutáneas ENL. Se ha mostrado que la Talidomida causa una reducción de la relación de linfocitos CD4 + a CD8 + en la sangre de los hombres sanos. Esta reducción se debe a una reducción significativa de linfocitis CD4 + y un aparente aumento de linfocitos CD8 + .

En este estudio, la ef ectividad de la Talidomida en parar el ENL crónico y detener una recaída de ENL, fue asociada constantemente con una reducción en el número de linfocitos CD $4+$, en la sangre de los hombres pacientes de lepra lepromatosa. 